\title{
Monoclonal antibodies developed for sensitive detection and comparison of white spot syndrome virus isolates in India
}

\author{
T. M. Anil, K. M. Shankar*, C. V. Mohan \\ Pathology and Biotechnology Laboratory, Department of Aquaculture, University of Agricultural Sciences, College of Fisheries, \\ Mangalore-575002, India
}

\begin{abstract}
Since its first report in 1994, white spot syndrome virus (WSSV) has become widespread in India. We have developed a simple, rapid and sensitive monoclonal antibody (MAb)-based immunodot test for detection of WSSV. Four MAbs of IgG isotype were produced against an Indian isolate of WSSV: $1 \mathrm{MAb}$ recognised a $28 \mathrm{kDa}$ viral protein while the other 3 recognised both 28 and $18 \mathrm{kDa}$ proteins. The $4 \mathrm{MAbs}$ recognised 4 different Indian WSSV isolates collected at different times from the east and west coasts of India, indicating antigenic uniformity of the isolates. The limit of detection of the immunodot test was $500 \mathrm{pg}$ of the viral protein, which compared well with 1 step PCR and could be used to detect WSSV in shrimp Penaeus monodon with and without gross signs of white spots in the cuticle. Furthermore, the test was rapid ( $3 \mathrm{~h}$ for completion) and is suitable for further development as a simple field kit.
\end{abstract}

KEY WORDS: WSSV $\cdot$ Monoclonal antibodies $\cdot$ Immunodot $\cdot$ India

Resale or republication not permitted without written consent of the publisher

\section{INTRODUCTION}

White spot syndrome virus (WSSV) is a significant pathogen of cultured shrimp all over the world, but especially in Asia, including India, since 1993. It is a rod-shaped, double-stranded DNA virus affecting tissues of ectodermal and mesodermal origin in penaeids, and it results in mass mortalities. In addition, other crustaceans such as crabs, copepods, lobsters, prawns and krill act as asymptomatic carriers of the virus (Yu et al. 1995, Flegel 1996, Lo et al. 1996, Chang et al. 1998, Supamattaya et al. 1998, Rajendran et al. 1999, Chen et al. 2000, Corbel et al. 2001). Dual infection of Penaeus monodon with WSSV and yellow head virus (YHV) (Mohan et al. 1998, Sithigorngul et al. 2000) has also been reported. WSSV infection has been detected by conventional histopathology (Wongteerasupaya et al. 1995, Lightner 1996, Lo et al. 1997, Kasornchandra et al. 1998, Mohan et al. 1998) and electron microscopy

${ }^{*}$ Corresponding author. E-mail: kmshankar@eudoramail.com
(Takeshi et al. 1995, Durand et al. 1996, Flegel 1996, Lo et al. 1996, Nadala et al. 1998). Genome based diagnostics such as DNA hybridisation (Chang et al. 1996, Durand et al. 1996) and PCR (Lo et al. 1996, Takahashi et al. 1996, Kim et al. 1998) have also been developed for its detection. Antigen analysis of the virus has been carried out using polyclonal rabbit antisera, also used for immunodiagnosis (Nadala et al. 1997, 1998, Hameed et al. 1998, Loh et al. 1998). Recently, monoclonal antibodies against the Chinese isolate of WSSV have also been produced and characterised (Yu et al. 1995, Zhan et al. 1999, Poulos et al. 2001, Shih et al. 2001).

In India, shrimp culture is practiced over 150000 ha. WSSV was first seen in India in 1994 (Mohan et al. 1998) and is now widespread throughout the country (Shankar \& Mohan 1998), causing huge financial losses. PCR is used to screen postlarvae for WSSV, but although it is highly sensitive in WSSV detection, there are practical limitations to its widespread application, including the high costs involved in setting up a laboratory with special equipment and well-trained personnel (Sithigorngul et al. 2000). Furthermore, several 
studies (Lo et al. 1998, Tsai et al. 1999) have indicated that results positive by the highly sensitive 2-step PCR (nested PCR) are not always associated with pond outbreaks and may have a limited value for field prognosis. However, stocking of seed positive by 1-step PCR is strongly associated with outbreaks (Withyachumnarnkul 1999). Therefore, the highest priority should be to exclude broodstock and seed with high levels of infection. This would require application of less-sensitive PCR (1-step) or an alternative screening procedure of similar sensitivity. In this context, we attempted to develop a simple and sensitive monoclonal antibody (MAb)-based assay that would be suitable for fieldlevel screening of shrimp for WSSV.

MAb-based tests such as immunofluorescence (Zhan et al. 1999, Shih et al. 2001), immunoperoxidase and whole-mount tissue assays (Poulos et al. 2001) have been developed for detection of the Chinese isolate of WSSV. However, such tests are not ideally suited for field level screening by farmers. Furthermore, there is evidence that the various WSSV geographic isolates differ at the molecular level (Nadala \& Loh 1998, Lo et al. 1999, Wang et al. 2000a) and in virulence (Wang et al. 1999). There are possibly also several variants in any country/region due to long-term intensive shrimp culture and traffic in seed. Thus, we have produced monoclonal antibodies to the Indian isolate of WSSV for antigen characterisation and for development of a simple and sensitive farmer-level immunodot test. The performance of the test was compared with PCR for screening shrimp from WSS outbreaks.

\section{MATERIALS AND METHODS}

Virus collection and purification. Tiger shrimp Penaeus monodon, with gross signs of white spots in the cuticle, were collected from a WSS-outbreak farm in Kundapur on the west coast of India. WSSV infection was confirmed by histopathology and polymerase chain reaction (PCR) (Lo et al. 1996). The foregut, gill, and epithelial tissue from the cepahalothorax were separated from the shrimp and homogenised in TNE buffer $(0.2 \mathrm{M}$ $\mathrm{NaCl}, 0.02 \mathrm{M}$ Tris $\mathrm{HCl}$ and 0.02M EDTA, pH 7.4) at 1:10 $\mathrm{w} / \mathrm{v}$. The homogenate was centrifuged at $4000 \times g$ for $10 \mathrm{~min}$ and the supernatant further centrifuged at 10000 $\times g$ for 10 min to remove cell debris. Then the supernatant was pelleted at $100000 \times g$ (Sorval 80 , rotor T-880) for $1 \mathrm{~h}$. The pellet was resuspended in TNE buffer and overlayered onto a discontinuous sucrose gradient (10, 30,40 , and $50 \%$ ) and centrifuged at $100000 \times g$ (rotor AH-650) for $1 \mathrm{~h}$. Virus bands between 30 and $50 \%$ were collected, diluted with TNE and pelleted at $100000 \times g$ for $1 \mathrm{~h}$. The pellet was re-suspended in PBS and stored at $-20^{\circ} \mathrm{C}$. Purity of the viral preparation was checked by electron microscopy and SDS-PAGE. WSSV-infected shrimp were collected from several places (Kakinada, Nellore, Madras) along the east coast of India for similar purification and epitope analysis.

Production of hybridomas. Hybridomas were produced according to Kohler \& Milstein (1975) with modifications (Shankar \& Yamamoto 1994): 8 wk old female Balb/c mice were immunised (i.p.) with the purified virus (30 $\mu$ g protein) mixed 1:1 with Freund's complete adjuvant. A similar second injection dose (i.p.) was given with the purified virus in Freund's incomplete adjuvant (1:1) 15 d later. On Day 27, a booster dose of $0.05 \mathrm{ml}$ virus (3.1 $\mu \mathrm{g}$ protein) was given (i.v.). Antibody titre to WSSV in the mice was checked by an indirect enzyme-linked immunosorbent assay (ELISA), and mice with titres greater than 1:1000 were sacrificed on Day 31 for collection of spleen cells.

Spleen cells from the immunised mice were fused with $\mathrm{SP}_{2} / \mathrm{O}$ myeloma cells using polyethylene glycol of 1500 and 3400 mol. wt (Sigma Chemicals, USA) at a ratio of 80:20. The fused cells were re-suspended in RPMI-HAT medium and $0.1 \mathrm{ml}$ was transferred to each well of a 96well tissue culture plate layered with mouse spleen cellfeeder. The cells were incubated at $5 \% \mathrm{CO}_{2}$ in a humidified incubator. On Day 8 post-fusion, $50 \%$ of the medium was replaced with fresh RPMI-HT. Hybridomas were screened for antibody production from Day 10 onwards employing an immunodot assay. Positive clones were minicloned 3 times before characterisation of antibodies was undertaken.

Development of immunodot assay for screening hybridomas. Purified virus preparations and tissue (gill, foregut and epithelial layer from the cephalothorax) homogenates from normal healthy shrimp (2-step PCR negative) were dotted ( $3 \mu$ l) onto nitrocellulose (NC) paper which was then cut into squares of $6 \mathrm{~mm}^{2}$ and transferred to wells of a 96-well tissue culture plate. Free sites on the nitrocellulose were blocked with $3 \%$ BSA in PBS for $2 \mathrm{~h}$ and washed 3 times with PBS. Hybridoma culture supernatant from each well was added to the virus and normal tissue dots and incubated overnight. After washing with PBS-Tween 20 (0.05\%), rabbit anti-mouse IgG horse raddish peroxidase (HRP) (Genei, Bangalore, India) in $3 \%$ BSA in PBS $(1: 100)$ was added and incubated for $90 \mathrm{~min}$. After washing with PBS-Tween, $100 \mu \mathrm{l}$ of substrate $\left(100 \mu \mathrm{l}\right.$ of 4 -chloro-1-naphthol at $3 \mathrm{mg} \mathrm{ml}^{-1}$ in ethanol, $10 \mu \mathrm{l}$ of $30 \% \mathrm{H}_{2} \mathrm{O}_{2}, 10 \mathrm{ml}$ of Tris buffer $\mathrm{pH}$ 7.6) was added. Clear purple-blue dot development on NC paper was considered positive. Hybridoma supernatants reacting with the purified virus but not with normal healthy shrimp tissue-homogenate were considered positive. Supernatants of positive hybridomas were tested for their reaction with SDS-mercaptoethanol-treated virus preparation and positive clones were subjected to Western blot analysis. 
Immunohistochemistry. Formalin fixed cephalothoraxes of WSSV-infected and uninfected shrimps were embedded in paraffin wax, cut into $5 \mu \mathrm{m}$ sections, and transferred to microscope slides for heat-fixing overnight at $56^{\circ} \mathrm{C}$. Sections were de-waxed using xylene and rehydrated through a series of alcohol and distilled water. Slides were washed in PBS buffer and nonspecific binding sites blocked with $500 \mu \mathrm{l}$ of $10 \%$ normal rabbit serum in $1 \%$ BSA in PBS for 30 min in a humidified chamber. After removing the serum and washing with PBS, tissue sections were reacted with cell culture supernatant of positive hybridomas for 45 min. After washing the slides in PBS, rabbit antimouse IgG horse radish peroxidase (Genei, Bangalore) diluted 1:200 in 1\% BSA in PBS was added and incubated for $30 \mathrm{~min}$. After washing, diaminobenzidine (Sigma Chemicals, USA) $\left(0.6 \mathrm{mg} \mathrm{m}^{-1} 0.05 \mathrm{mM}\right.$ Tris buffer, $\mathrm{pH} 7.6$, with $0.03 \% \mathrm{H}_{2} \mathrm{O}_{2}$ ) was added. After $5 \mathrm{~min}$, the slides were immersed in tap water and then counterstained with $0.1 \%$ eosin for $3 \mathrm{~min}$. The tissues were dehydrated in alcohol, dipped in xylene and mounted with DPX mountant for microscopic observations. Tissue sections from the WSSVinfected shrimp were also stained with haematoxylin and eosin for comparison. Uninfected shrimp tissue sections incubated with MAbs were used as negative controls. A dark brown color development in the tissue was considered a positive reaction.

Characterisation of monoclonal antibodies (MAbs). Western blot analysis and isotype determination were carried out as follows:

Western blot analysis: Purified virus preparation and molecular markers (Sigma Chemicals) were mixed with reducing buffer at $1: 4(\mathrm{v} / \mathrm{v})$, boiled at $100^{\circ} \mathrm{C}$ for $5 \mathrm{~min}$, and loaded onto a $12.5 \%$ SDS gel. Electrophoresis was at a constant current of $25 \mathrm{~mA}$ for $1 \mathrm{~h}$ (Laemmli 1970). Separated proteins were either stained with Coomassie blue or transferred to nitrocellulose paper at $250 \mathrm{~mA}$ for $1 \mathrm{~h}$ using a mini-transblot apparatus (Bio Rad). Multiple protein lanes on the nitrocellulose were cut and reacted with blocking solution $(3 \%$ BSA in PBS). One lane was stained with amido black, while others were reacted separately with each MAb (4 d-old cell culture supernatant) overnight at $4^{\circ} \mathrm{C}$. After washing 3 times, proteins were reacted with rabbit anti-mouse IgG HRP (Genei) in $3 \%$ BSA in PBS (1:200) for $1 \mathrm{~h}$. Substrate consisting of 4 chloro-1-naphthol and $\mathrm{H}_{2} \mathrm{O}_{2}$ was added after washing 3 times with PBS-Tween, and any purple-blue colour development was recorded.

Isotype determination: The immunoglobulin isotype of the MAbs was determined using a capture ELISA kit (Sigma Chemicals) according to the manufacturer's instructions. Tetramethyl benzidine was used as the chromogen with the substrate.
Development of MAb-based immunodot test for diagnosis. Specificity, epitope analysis, sensitivity, detection limits and field performance were examined as follows:

Determination of specificity: Antigen ( $3 \mu \mathrm{l})$ from a purified virus preparation, homogenates of gill tissue from WSSV-infected shrimp, and homogenates of gills, cephalothorax, epithelium and foregut of uninfected healthy Penaeus monodon were dotted onto prewashed and dried nitrocellulose paper. In addition, $3 \mu \mathrm{l}$ homogenate from the hepatopancreas of MBV (monodon baculovirus)-infected $P$. monodon (as confirmed by histopathology and Malachite green staining) was dotted for comparison. The immunodot test was performed as described above, employing $4 \mathrm{~d}$-old cell culture supernatants of hybridomas. Reaction time with MAb and conjugate were adjusted to 90 and 30 min respectively so that the whole assay could be performed within $3 \mathrm{~h}$. The test was later repeated with other MAbs against the homologous virus. Specific reactions of the MAbs with viral antigens and WSSV-infected tissue were compared to those for normal shrimp tissue and MBV.

Epitope analysis of different WSSV isolates in India: An epitope analysis of WSSV isolates from different places in India was carried out by an immunodot test using the panel of 4 MAbs: 4 isolates collected from different places along the east and west coast of India were used. Tissues (gills, foregut and cephalothorax epithelial layer) were homogenised separately in TNE buffer and centrifuged at $4250 \times g$ followed by dotting $3 \mu \mathrm{l}$ of each sample homogenate onto four NC strips and air drying. The strips were incubated with MAbs separately and the reactions were recorded as described above.

Determination of sensitivity: The homologous virus isolate from Kundapur was purified by banding twice on sucrose gradient by ultracentifugation. The protein concentration was estimated according to Lowry et al. (1951). Later, serial double dilutions of the purified virus preparation were made and an appropriate volume from each dilution was dotted onto an NC sheet. A negative control without virus antigen was used for comparison. The NC strip was then reacted with MAb C38 (4 d-old cell culture supernatent) in an immunodot test as described above.

Limit of detection of immunodot test compared to PCR: The limit of viral detection by the immunodot and PCR methods was determined. Gills from 5 WSSVinfected Penaeus monodon were separately ground to paste in a sterile mortar, weighed, and divided equally into 2 halves, 1 half for the immunodot assay and the other for PCR. The half for the immunodot was resuspended in TNE buffer $(1: 10 \mathrm{w} / \mathrm{v})$ and centrifuged at $4250 \times g$ and the supernatant was subjected to $10 \times$ serial dilutions. Suspension $(3 \mu \mathrm{l})$ from each dilution was dotted onto NC paper and an immunodot test was car- 


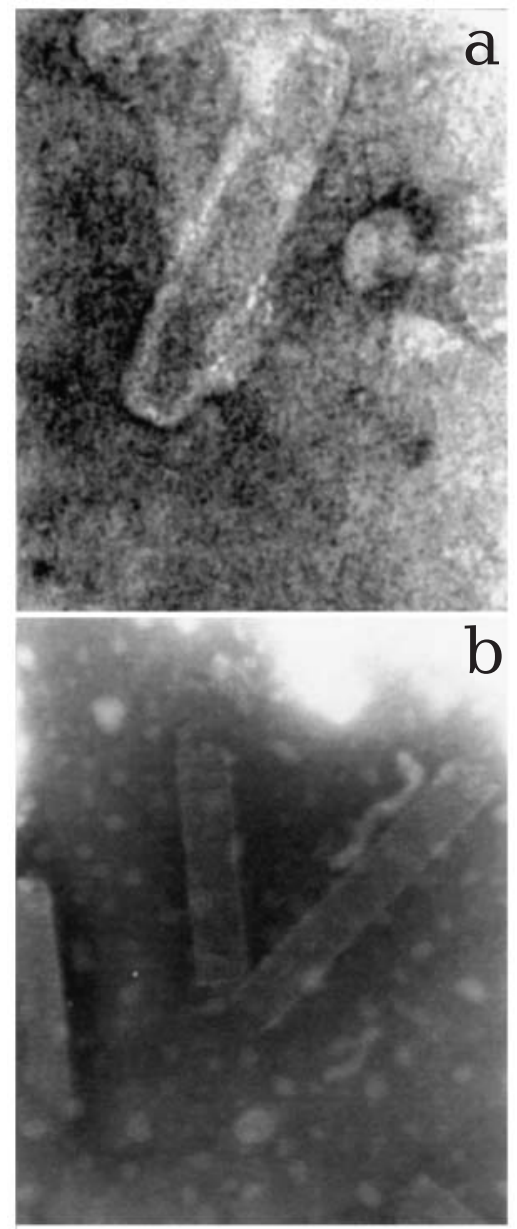

Fig. 1. Electron micrographs of a purified preparation of white spotsyndrome virus (WSSV); the virus was negatively stained with phosphotungstate. (a) Intact WSSV with envelope (×90 000); (b) WSSV nucleocapsid $(\times 75000)$

ried out as described above. The half for PCR was treated according to Lo et al. (1996) with a few modifications (Thakur et al. 2002). The paste was suspended in DNA-extraction buffer (1:10 w/v) and DNA was extracted by an alkaline method followed by serial $10 \times$ dilution. DNA extract $(3 \mu \mathrm{l})$ from each dilution was used for PCR. The positive end-point for the highest dilution in the PCR and immunodot test were compared.

Performance of immunodot test with field shrimp samples. Sixty Penaeus monodon samples from various farms in Kundapur with WSS outbreaks were collected individually, washed in distilled water, and packed separately to avoid cross-contamination during transport to the laboratory. From each shrimp, 4 gills were used for the PCR and immunodot tests. For the immunodot tests, gills were homogenised in TNE buffer $(1: 10 \mathrm{w} / \mathrm{v})$ and $3 \mu \mathrm{l}$ of the homogenate was used. Gills for PCR were fixed in methanol, DNA was extracted with buffer $(1: 10 \mathrm{w} / \mathrm{v})$ and $3 \mu \mathrm{l}$ of the extract was used. The PCR and immunodot tests were carried out as described above with appropriate positive and negative controls.

\section{RESULTS}

\section{Virus purification}

Electron micrographs of the virus purified by sucrose gradient centrifugation are shown in Fig. 1. Rodshaped viral nucleocapsids and intact virus particles with an envelope were observed in the preparation. Three viral proteins (28, 24 and $18 \mathrm{kDa}$ ) were differentiated by SDS-PAGE and Western blot analysis (Fig. 2).

\section{Production of hybridomas}

From 4 fusions, we obtained 500 hybridomas; of these, 83 reacted with the purified virus and not with normal shrimp antigen. Of these 83 clones, supernatants of only 35 clones reacted with SDS-mercaptoethanol-treated virus preparations in the immunodot assays. Finally, 4 positive stable clones designated C5, C33, C38 and C56 that reacted with WSSV in Western blots were selected for further cloning, characterisation and development of an immunodot test.

\section{Characterisation of MAbs}

In the Western blot test (Fig. 2) 1 MAb (C33) reacted with a $28 \mathrm{kDa}$ protein of the virus, and 3 MAbs (C5,

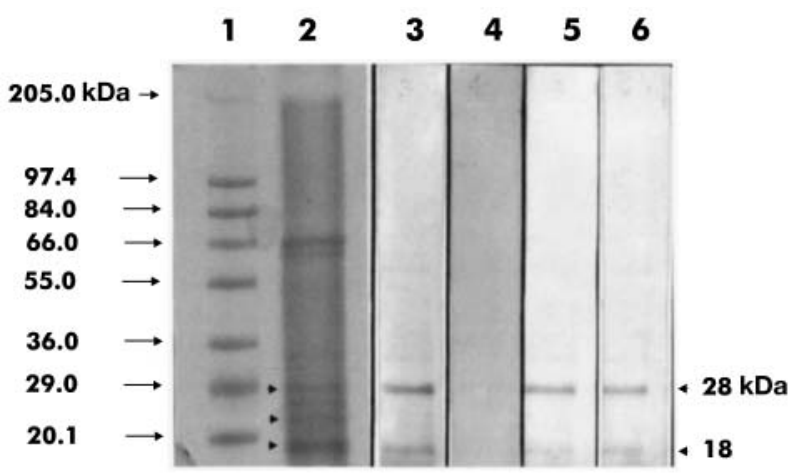

Fig. 2. Determination of WSSV protein-specificity of MAbs by Western blot analysis. Purified virus preparations were subjected to $12.5 \%$ SDS-PAGE; proteins were transferred to nitrocellulose (NC) paper and reacted with monoclonal antibodies (MAbs). Lane 1: molecular weight markers; Lane 2: viral proteins from sucrose gradient-purified WSSV preparations; Lane 3: MAb C5; Lane 4: MAb C33; Lane 5: MAb C38; Lane 6: MAb C56 


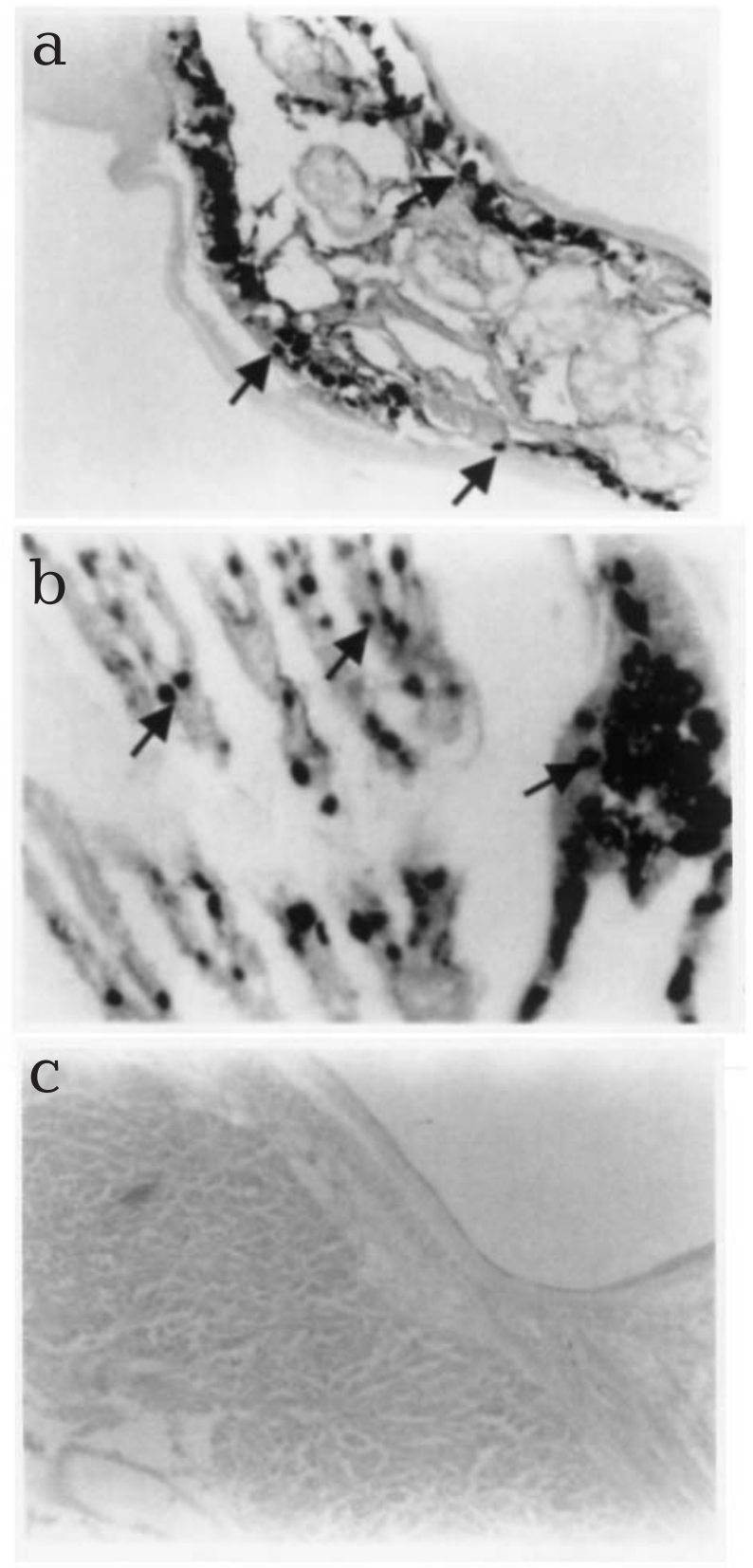

Fig. 3. Penaeus monodon. Determination of specificity of MAbs by immunohistochemistry. Reaction of MAb C38 with WSSV-infected cuticular epithelium (a), gills (b) and normal healthy cuticular epithelium (c). Positive immunoperoxidase reaction is indicated by arrows. (a) and (c) $=\times 200$; (b) $=\times 400$
Table 1. Penaeus monodon. Characteristics of MAbs reaction to WSSV. -: no reaction; +: weak reaction; ++: strong reaction; +++ : very strong reaction

\begin{tabular}{|lcccc|}
\hline MAbs & $\begin{array}{c}\text { Class } \\
\text { sub-class }\end{array}$ & $\begin{array}{c}\text { Reactivity to } \\
\text { WSSV protein } \\
\text { (kDa) }\end{array}$ & \multicolumn{2}{c|}{ Intensity of reaction at: } \\
\hline C-5 & IgG1 & 28,18 & ++ & $18 \mathrm{kDa}$ \\
C-33 & IgG1 & 28 & + & + \\
C-38 & IgG2a & 28,18 & +++ & + \\
C-56 & IgG1 & 28,18 & ++ & + \\
\hline
\end{tabular}

$\mathrm{C} 38$ and $\mathrm{C} 56$ ) reacted (in addition to the $28 \mathrm{kDa}$ protein) to an $18 \mathrm{kDa}$ protein, although weakly (Table 1). Of the 4 MAbs, C-38 reacted very strongly in both Western blot and immunodot tests.

\section{Development of an immunodot test}

\section{Specificity}

The specific reaction of the MAbs with WSSV was confirmed by immunohistochemistry. The specific reaction of MAb C38 with WSSV is shown in Fig. 3. Nuclei of infected cells clearly stained with the substrate diaminobenzidine (DAB). Furthermore MAbs reacted in the immunodot test specifically with purified virus and WSSV-infected tissue and not with tissue from normal healthy shrimp (Fig. 4). They did not react with MBV. The total time taken for the test including antigen dotting for detection of WSSV in clinical samples was $3 \mathrm{~h}$. However, the test could be performed in $2 \mathrm{~h}$ for detection of WSSV in acute infections from shrimp showing gross signs of white spots in the cuticle.

\section{Epitope analysis}

All 4 MAbs recognised the 4 isolates from the east and west coasts of India (Fig. 5). Thus, there was no difference in epitopes among the isolates as determined by the 4 MAbs. However, the colour intensity of the dots varied among the different isolates, in that they were somewhat lighter for the isolate from Madras.
Fig. 4. Penaeus monodon. Development of immunodot test with MAb C38 for field detection of WSSV. Homogenates of gill tissue of shrimp from various WSS outbreak farms were dotted onto NC and immunodot tests were carried out with MAb C38. A1: positive control; B1: negative control with normal shrimp gill; A2: homogenate of hepatopancreas of a shrimp infected with monodon baculovirus. Specimens B3, C2, D2 are WSSV-negative; A3, A4, B2, B4, C1, C3, C4, D1, D3 and D4 are WSSV-positive

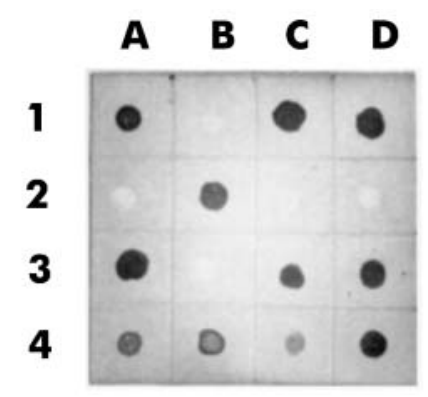


Sensitivity

Using MAb C38, the immunodot test could detect as little as $500 \mathrm{pg}$ of purified virus preparation (Fig. 6). The detection level could be enhanced to 400 pg by increasing the MAb incubation time to overnight.

\section{Limit of detection}

The virus could be detected at $10^{-3}$ dilution of infected shrimp tissue homogenate by both the PCR (1step) and immunodot test in 4 shrimp and at $10^{-2}$ dilution in 1 shrimp (Table 2, Fig. 7). The results indicated that the detection level by the immunodot test matched that of 1-step PCR (Lo et al. 1996).

\section{Performance of immunodot test with shrimp samples from WSS outbreaks}

A comparison of the immunodot test with PCR tests for detection of WSSV in field samples of shrimp is shown in Tables $3 \& 4$. The immunodot test detected WSSV similar to PCR in all 30 samples showing gross signs of white spots. However, the immunodot could detect WSSV in only 21 of the 22 PCR-positive shrimp without these gross signs. Thus, the overall performance level of the immunodot for detection of WSSV was $98 \%$ compared with 1-step PCR.

\section{DISCUSSION}

Three proteins of 28, 24 and $18 \mathrm{kDa}$ were recorded from the Indian isolates of WSSV. This agrees with the

Table 2. Penaeus monodon. Limit of detection for the immunodot (I. dot) test in comparison with 1-step PCR for detection of WSSV in shrimp

\begin{tabular}{|c|c|c|c|c|c|c|c|c|}
\hline \multirow{2}{*}{$\begin{array}{l}\text { Shrimp } \\
\text { sample }\end{array}$} & \multirow[t]{2}{*}{ Test } & \multicolumn{6}{|c|}{ _ Dilution } & \multirow{2}{*}{$\begin{array}{c}\text { Negative } \\
\text { control }\end{array}$} \\
\hline & & $10^{-1}$ & $10^{-2}$ & $10^{-3}$ & $10^{-4}$ & $10^{-5}$ & $10^{-6}$ & \\
\hline \multirow[t]{2}{*}{ A } & PCR & + & + & + & - & - & - & - \\
\hline & I. dot & + & + & + & - & - & - & - \\
\hline \multirow[t]{2}{*}{ B } & PCR & + & + & + & - & - & - & - \\
\hline & I. dot & + & + & + & - & - & - & - \\
\hline \multirow[t]{2}{*}{$\mathrm{C}$} & PCR & + & + & + & - & - & - & - \\
\hline & I. dot & + & + & + & - & - & - & - \\
\hline \multirow[t]{2}{*}{$\mathrm{D}$} & PCR & + & + & - & - & - & - & - \\
\hline & I. dot & + & + & - & - & - & - & - \\
\hline \multirow[t]{2}{*}{$\mathrm{E}$} & PCR & + & + & + & - & - & - & - \\
\hline & I. dot & + & + & + & - & - & - & - \\
\hline
\end{tabular}

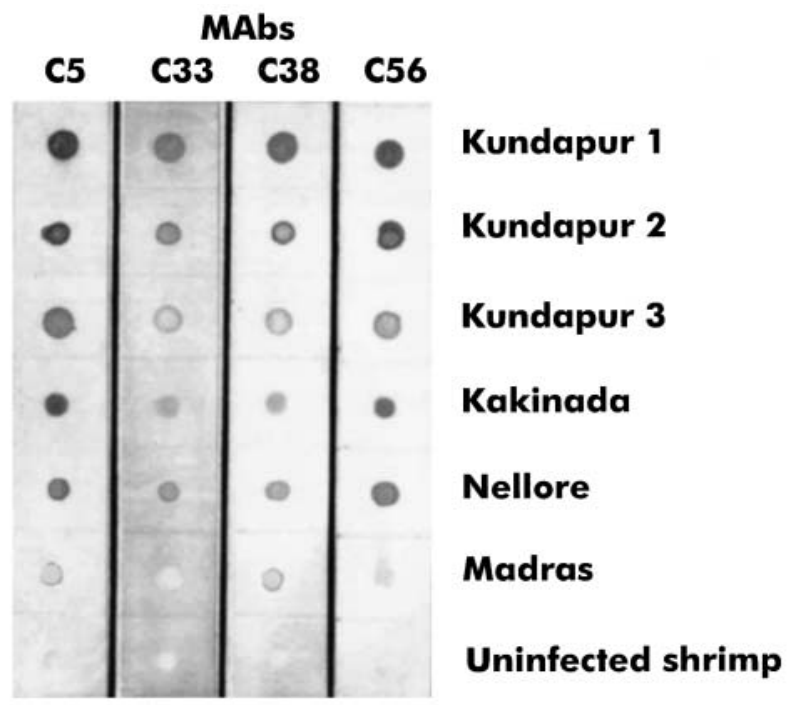

Fig. 5. Penaeus monodon. Epitope analysis of WSSV isolates by MAbs. Gill homogenate of WSSV-infected shrimp from different regions along the east and west coasts of India dotted onto NC and tested with the 4 MAbs.

findings of Hameed et al. (1998) and those of other studies on Asian WSSV isolates (Nadala \& Loh 1998, Nadala et al. 1998, Wang et al. 2000b). Of the 4 MAbs, $1 \mathrm{MAb}$ (C33) reacted with the $28 \mathrm{kDa}$ protein, which is an envelope protein (Nadala et al. 1998, van Hulten et al. 2000a,b); 3 MAbs (C5, C38, C56) (in addition to the $28 \mathrm{kDa}$ protein) also reacted weakly with the $18 \mathrm{kDa}$ protein, also an envelope protein (Nadala et al. 1998, van Hulten et al. 2000a). Similar observations have been made by Poulos et al. (2001), where one MAb for WSSV reacted with both envelope proteins. It appears that these envelope proteins share common epitopes. Since our hybridoma clones were minicloned thrice at high log dilution, they were considered truly monoclonal. Among the various WSSV proteins, the $28 \mathrm{kDa}$ protein has been found to be dominant and highly immunogenic (Hameed et al. 1998, Nadala et al. 1998, Poulos et al. 2001). However, an MAb reacting only with the $19 \mathrm{kDa}$ protein has also been produced (Shih et al 2001). The 4 MAbs differed in reactivity with the viral proteins, as indicated by the intensity of colour in the Western blot and immunodot tests. Since the reaction of C38 was strongest, it was employed in the development of the immunodot test.

In the immunodot test, the MAbs specifically reacted with purified virus, virus infected tissue but not with tissue of normal healthy shrimp (PCR 2-step 


\section{Viral protein concentration (in $\mathbf{n g}$ )}

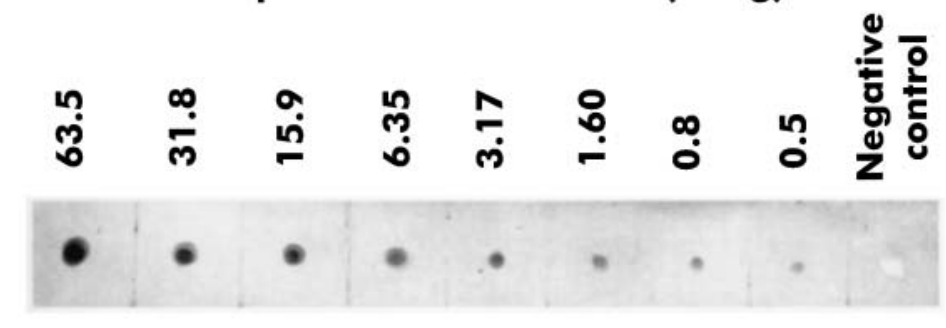

Fig. 6. Penaeus monodon. Sensitivity of the MAb-based immunodot test. Purified WSSV preparation was 2-fold serially diluted and dotted on NC along with homogenates from non-infected shrimp as the control for testing with MAb C38

Table 3. Penaeus monodon. Comparative performance of the immunodot (I. dot) test with 1-step PCR for detection of WSSV in WSSV-outbreaks. No: gross signs of white spot absent; Yes: gross signs of white spot present; nr: not recorded

\begin{tabular}{|c|c|c|c|c|c|c|c|}
\hline $\begin{array}{l}\text { Shrimp } \\
\text { sample no. }\end{array}$ & $\begin{array}{l}\text { Gross } \\
\text { signs }\end{array}$ & PCR & I. dot & $\begin{array}{l}\text { Shrimp } \\
\text { sample no }\end{array}$ & $\begin{array}{l}\text { Gross } \\
\text { signs }\end{array}$ & PCR & I. dot \\
\hline S1 & No & - & - & S31 & Yes & + & + \\
\hline S2 & No & + & + & S32 & Yes & + & + \\
\hline S3 & No & + & + & S33 & Yes & + & + \\
\hline S4 & No & + & + & S34 & Yes & + & + \\
\hline S5 & No & + & + & S35 & Yes & + & + \\
\hline S6 & No & + & + & S36 & Yes & + & + \\
\hline S7 & No & - & - & S37 & Yes & + & + \\
\hline S8 & No & + & - & S38 & Yes & + & + \\
\hline S9 & No & + & + & S39 & Yes & + & + \\
\hline $\mathrm{S} 10$ & No & - & - & S40 & $\mathrm{nr}$ & + & + \\
\hline $\mathrm{S} 11$ & Yes & + & + & S41 & $\mathrm{nr}$ & + & + \\
\hline $\mathrm{S} 12$ & Yes & + & + & S42 & $\mathrm{nr}$ & + & + \\
\hline S13 & Yes & + & + & S43 & $\mathrm{nr}$ & + & + \\
\hline S14 & Yes & + & + & S44 & $\mathrm{nr}$ & + & + \\
\hline S15 & Yes & + & + & S45 & $\mathrm{nr}$ & + & + \\
\hline S16 & Yes & + & + & S46 & $\mathrm{nr}$ & + & + \\
\hline S17 & Yes & + & + & S47 & $\mathrm{nr}$ & + & + \\
\hline S18 & Yes & + & + & S48 & $\mathrm{nr}$ & + & + \\
\hline S19 & Yes & + & + & S49 & $\mathrm{nr}$ & + & + \\
\hline S20 & Yes & + & + & S50 & $\mathrm{nr}$ & - & - \\
\hline S21 & Yes & + & + & S51 & $\mathrm{nr}$ & - & - \\
\hline S22 & Yes & + & + & S52 & No & + & + \\
\hline $\mathrm{S} 23$ & Yes & + & + & S53 & No & + & + \\
\hline $\mathrm{S} 24$ & Yes & + & + & S54 & No & - & - \\
\hline $\mathrm{S} 25$ & Yes & + & + & S55 & No & - & - \\
\hline S26 & Yes & + & + & S56 & No & - & - \\
\hline S27 & Yes & + & + & S57 & No & + & + \\
\hline S28 & Yes & + & + & S58 & No & + & + \\
\hline S29 & Yes & + & + & S59 & No & + & + \\
\hline S30 & Yes & + & + & S60 & Yes & + & + \\
\hline
\end{tabular}

Table 4. Penaeus monodon. Summary of the performance of the 1-step PCR and immunodot (I.dot) test for detection of WSSV in shrimp in WSSV-outbreaks

\begin{tabular}{|llccc|}
\hline $\begin{array}{l}\text { Sample } \\
\text { no. }\end{array}$ & WSSV infection & $\begin{array}{c}\text { No. of } \\
\text { samples }\end{array}$ & $\begin{array}{c}\text { PCR } \\
\text { +ve }\end{array}$ & $\begin{array}{c}\text { I. dot } \\
\text { +ve }\end{array}$ \\
\hline 1 & With clinical white spots & 30 & 30 & 30 \\
2 & Without clinical white spots & 18 & 12 & 11 \\
3 & Clinical signs not recorded & 12 & 10 & 10 \\
\hline
\end{tabular}

negative). As expected, the antibodies did not react with monodon baculovirus (MBV). Although the tissue specificity of WSSV and MBV differs, the latter is ubiquitous and widely prevalent in India. Hence, it was important to study the reaction of the MAbs with the virus for development of a diagnosis.

Although the 4 MAbs reacted with all 4 WSSV isolates from the east and west coasts of India, there were differences in reaction intensity. It was low in the isolate from Madras, but this may have been due to a difference in virus quantity. As such, we feel that there were no reaction differences between the 3 isolates from Kundapur collected at different times. Overall, there were no differences in epitopes among the 4 Indian WSSV isolates with these 4 MAbs, suggesting antigenic uniformity and suitability of the MAbs for detection of WSSV throughout India. However, a larger panel of MAbs is required to be certain that epitope differences do not occur among isolates in India. Furthermore, due to the relative homogeneity of WSSV, it is likely (although not specifically tested) that the MAbs would react with WSSV not only from India, but also from other countries.

The immunodot test is sensitive and capable of detecting $500 \mathrm{pg}$ of purified virus employing $4 \mathrm{~d}$-old cell culture supernatant. The sensitivity could be increased to $400 \mathrm{pg}$ by increasing MAb incubation time to $12 \mathrm{~h}$. This sensitivity level matches that of an MAb-based immunodot test initially designed by Hawkes et al. (1982). There is further scope to increase the sensitivity of the immunodot assay by using concentrated cell culture supernatant. Earlier, Hameed et al. (1998) used a rabbit antiserum-based immunodot test which could detect $800 \mathrm{ng}$ of hemolymph protein from WSSV-infected shrimp. However, a rabbit antiserum-based immunodot test for detection of the yellow head virus in shrimp with a sensitivity level of $400 \mathrm{pg}$ has been reported (Lu et al. 1996). According to Poulos et al. (2001), the immunodot test is excellent for screening WSSV but is not sensitive 


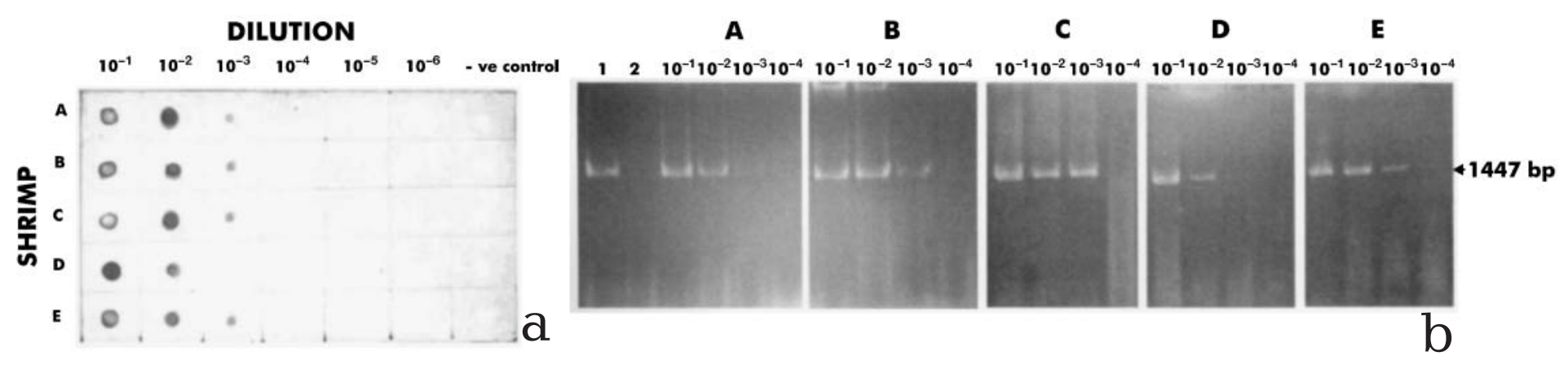

Fig. 7. Penaeus monodon. Determination of limit of detection of WSSV by immunodot test and PCR. Gill tissues collected from 5 shrimp (A to E) from a WSS outbreak farm were separately ground to a paste and divided into 2 equal parts. The gill homogenate and DNA extract from the gill paste were subjected to serial 10x dilutions before tests by immunodot (a) and 1-step PCR (b). In panel $\mathrm{A}$ of (b), Lane 1 = positive control and Lane 2 = negative control

in screening clinical samples. However, Poulos et al. did not show sensitivity of their immunodot assay for WSSV. In our study, the limit of detection of the immunodot test matched that of 1-step PCR (Lo et al. 1996). The immunodot test clearly detected the virus at levels similar to that of 1-step PCR in samples with and without gross white spots. This finding is very important and has practical implications, as it has been demonstrated that 2-step PCR results are not good predictors for field outbreaks of WSS, while 1-step PCR results are (Lo et al. 1998, Tsai et al. 1999). This has been amply demonstrated by Withyachumnarnkul (1999), who showed a strong agreement between 1step PCR results and outbreaks of WSS in cultivation ponds. In additon, 1-step PCR results have been found to be more meaningful for screening shrimp broodstock (Hsu et al. 1999). Broodstock shown to be WSSpositive by 1-step PCR have a higher prevalence of WSSV in their progeny than broodstock shown to be WSS-positive by 2-step PCR. Thus, our immunodot test could be a practical alternative to PCR.

Falsely positive results are a serious problem with PCR (Kwok \& Higuchi 1989), hence this could prove a problem in management. The scope for such falsely positive results is less with the immunodot method, which detects the available protein copies actually present in the sample. The test is very simple and could be readily adapted to formats simple enough to be used by farmers with no sophisticated equipment. The total time required for detection of WSSV infection in field samples was $3 \mathrm{~h}$, and this could be reduced to $2 \mathrm{~h}$ for samples with acute infection. Overall, there is further scope for reducing time and increasing sensitivity of the test by using concentrated MAbs individually or in a cocktail.

Acknowledgements. The authors gratefully acknowledge funding support for the work from the Department of Biotechnology, Government of India, New Delhi.

\section{LITERATURE CITED}

Chang PS, Lo CF, Wang YC, Kou GH (1996) Identification of white spot syndrome associated baculovirus (WSSV) target organs in the shrimp Penaeus monodon by in situ hybridisation. Dis Aquat Org 27:131-139

Chang PS, Chen HC, Wang YC (1998) Detection of white spot syndrome associated baculovirus in experimentally infected wild shrimp, crab and lobsters by in situ hybridisation. Aquaculture 164:233-242

Chen LL, Lo CF, Chiu YL, Chang CF, Kou GH (2000) Natural and experimental infection of white spot syndrome virus (WSSV) in benthic larvae of mud crab Scylla serrata. Dis Aquat Org 40:157-161

Corbel V, Zuprizal, Shiz, Huang H, Sumartono, Arcier JM, Bonami JR (2001) Experimental infection of European crustaceans with white spot syndrome virus (WSSV). J Fish Dis 24:377-382

Durand S, Lightner DV, Nunan LM, Redman RM, Mari J, Bonami JR (1996) Application of gene probes as diagnostic tools for white spot baculovirus (WSSV) of penaeid shrimp. Dis Aquat Org 27:59-66

Flegel TW (1996) A turning point for sustainable aquaculture: the white spot virus in Asian shrimp culture. Aquaculture Asia 1:29-34

Hameed ASS, Anil Kumar M, Raj S, Jayaraman K (1998) Studies on pathogenicity of systemic ectodermal and mesodermal baculovirus and its detection in shrimp by immunological methods. Aquaculture 160:31-45

Hawkes R, Niday E, Gordon J (1982) A dot-immunobinding assay for monoclonal and other antibodies. Analyt Biochem 119:142-147

Hsu HC, Lo CF, Lin SC, Liu KF, Peng SE, Chang YS, Chen LL, Liu WJ, Kou GH (1999) Studies on effective PCR screening strategies for white spot syndrome virus (WSSV) detection in Penaeus monodon brooders. Dis Aquat Org 39:13-19

Kasornchandra J, Boonyaratpalin S, Itami T (1998) Detection of white spot syndrome in cultured shrimp in Asia: microscopic observation and polymerase chain reaction. Aquaculture 164:243-251

Kim CK, Kim PK, Sohn SG, Sim DS, Park MA, Heo MS, Lee TH, Lee JD, Jun HK. Jang KL (1998) Development of a polymerase chain reaction (PCR) procedure for the detection of baculovirus associated with white spot syndrome (WSSV) in penaeid shrimp. J Fish Dis 21:11-17

Kohler G. Milstein C (1975) Continuous culture of fused cells secreting antibody of predefined specificity. Nature 256: 495-497 
Kwok S, Higuchi R (1989) Avoiding false positives with PCR. Nature 339:237-238

Laemmli UK (1970) Cleavage of stuctural proteins during the assembly of the head of bacteriophage T4. Nature 227: 680-685

Lightner DV (1996) A hand book of shrimp pathology and diagnostic procedures for diseases of cultured penaeid shrimp. World Aquaculture Society, Baton Rouge, LA

Lo CF, Leu JH, Ho CH, Chen CH and 8 others (1996) Detection of baculovirus associated with white spot syndrome (WSSV) in penaeid shrimps using polymerase chain reaction. Dis Aquat Org 25:133-141

Lo CF, Ho CH, Chen CH, Liu KF and 9 others (1997) Detection and tissue tropism of white spot syndrome baculovirus (WSBV) in captured brooders of Penaeus monodon with a special emphasis on reproductive organs. Dis Aquat Org 30:53-72

Lo CF, Chang YS, Cheng CT, Kou GH (1998) Monitoring cultured shrimp for whitespot syndrome virus (WSSV) infection during their growth period by polymerase chain reaction. In: Flegel TW (ed) Advances in shrimp biotechnology. National Center for Genetic Engineering and Biotechnology, Bangkok, p 281-286

Lo CF, Hsu HC, Tsai MF, Ho CH, Peng SE, Kou GH, Lightner DV (1999) Specific DNA fragment analysis of different geographical clinical samples of shrimp white spot syndrome virus. Dis Aquat Org 35:175-185

Loh PC, Nadala ECB, Tapay LM, Lu Y (1998) Recent developments in immunological-based and cell culture protocols for the specific detection of shrimp viral pathogens. In: Flegel TW (ed) Advances in shrimp biotechnology, Proceedings of the Special Session on Shrimp Biotechnology, Fifth Asian Fisheries forum. National Centre for Genetic Engineering and Biotechnology Thailand. Multimedia Asia, Bangkok, p 225-259

Lowry OH, Rosebrough NJ, Farr AL, Randall RJ (1951) Protein measurement with Folin phenol reagent. J Biol Chem 193:265-275

Lu Y, Tapay LM, Loh PC (1996) Development of a nitrocellulose enzyme immunoassay for the detection of yellow head virus from penaeid shrimp. J Fish Dis 19:9-13

Mohan CV, Shankar KM, Kulkarni S, Sudha PM (1998) Histopathology of cultured shrimp showing gross signs of yellow head syndrome and white spot syndrome during 1994 Indian epizootics. Dis Aquat Org 34:9-12

Nadala ECB, Loh PC (1998) A comparative study of three different isolates of white spot virus. Dis Aquat Org 33: 231-234

Nadala ECB, Tapay LM, Cao S, Loh PC (1997) Detection of yellow head virus and Chinese baculovirus in penaeid shrimp by Western blot technique. J Virol Methods 69: 39-44

Nadala ECB, Tapay LM, Loh PC (1998) Characterisation of a non-occluded baculovirus-like agent pathogenic to penaeid shrimp. Dis Aquat Org 33:221-229

Poulos BT, Pantoja CR, Bradley-Dunlop D, Aguilar J, Lightner DV (2001) Development and application of monoclonal antibodies for the detection of white spot syndrome virus of penaeid shrimp. Dis Aquat Org 47:13-23

Rajendran KV, Vijayan KK, Santiago TC, Kroll RM (1999) Experimental host range and histopathology of white spot syndrome virus (WSSV) infection in shrimp, prawns, crabs and lobsters from India. J Fish Dis 22:183-191

Shankar KM, Mohan CV (1998) Epidemiological aspects of viral diseases of shrimp in India. J Aquacult Trop 13:43-49

Shankar KM, Yamamoto T (1994) Epitope analysis of IPN virus isolated from lake trout, Salvelinus namaycush by monoclonal antibodies. J Fish Dis 17:471-482
Shih HH, Wang CS, Tan LF, Chen SN (2001) Characterisation and application of monoclonal antibodies against white spot syndrome virus. J Fish Dis 24:143-150

Sithigorngul P, Chauychuwong P, Sithigorngul W, Longyanth S, Chaivisuthangkura P, Menasveta P (2000) Development of a monoclonal antibody specific to yellow head virus (YHV) from Penaeus monodon. Dis Aquat Org 42:27-34

Supamattaya K, Hoffmann RW, Boonyaratpalin S, Kanchanapham P (1998) Experimental transmission of white spot syndrome virus (WSSV) from black tiger shrimp Penaeus monodon to the sand crab Portunus pelagicus, mud crab Scylla serrata and krill Acetes sp. Dis Aquat Org 32:79-85

Takahashi Y, Itami T, Maeda M, Suzuki N and 9 others (1996) Polymerase chain reaction (PCR) amplification of bacilliform virus (RV-PJ) DNA in Penaeus japonicus Bate and systemic endodermal and mesodermal baculovirus (SEMBV) DNA in Penaeus monodon Fabricius. J Fish Dis 19:399-403

Takeshi K, Heiji N, Kazuo M, Keisuke Y, Kiyoshi I (1995) Purification of the rod shaped nuclear virus (RV-PJ) from kuruma shrimp, Penaeus japonicus. Fish Pathol 30:287-288

Thakur PC, Corsin F, Turnbull JF, Shankar KM and 5 others (2002) Estimation of prevalence of white spot syndrome virus (WSSV) by polymerase chain reaction in Penaeus monodon post-larvae at time of stocking in shrimp farms of Karnataka, India: a population-based study. Dis Aquat Org 49:235-243

Tsai MF, Kou GH, Liu HC, Liu KF, Chang CF, Peng-SE, Hsu HC, Wang CH, Lo CF (1999) Long-term presence of white spot syndrome virus (WSSV) in a cultivated shrimp population without disease outbreaks. Dis Aquat Org 38:107-114

van Hulten MCW, Goodal SD, Vlak JM (2000a) Three functionally diverged major structural proteins of white spot syndrome virus evolved by gene duplication. J Gen Virol 81:2525-2529

van Hulten MCW, Westernberg M, Goodal SD, Vlak JM (2000b) Identification of two major virion protein genes of white spot syndrome virus of shrimp. Virology 266: 227-236

Wang Q, White BL, Redman RM, Lightner DV (1999) Per os challenge of Litopenaeus vannamei postlarvae and Farfantepenaeus duorarum juveniles with six geographic isolates of white spot syndrome virus. Aquaculture 170:179-194

Wang Q, Nunan LM, Lightner DV (2000a) Identification of genomic variations among geographic isolates of white spot syndrome virus using restriction analysis and Southern blot hybridisation. Dis Aquat Org 43:175-181

Wang Q, Poulos BT, Lightner DV (2000b) Protein analysis of geographic isolates of shrimp white spot syndrome virus. Arch Virol 145:263-274

Withyachumnarnkul B (1999) Results from black tiger shrimp Penaeus monodon culture ponds stocked with postlarvae PCR-positive or -negative for white-spot syndrome virus (WSSV). Dis Aquat Org 39:21-27

Wongteerasupaya C, Vickers JE, Sriurairatana S, Nash GL and 6 others (1995) A non-occluded, systemic baculovirus that occurs in cells of ectodermal and mesodermal origin and causes high mortality in the black tiger prawn Penaeus monodon. Dis Aquat Org 21:69-77

Yu J, Huang J, Song X, Yang C (1995) Preparation of monoclonal antibody against hypodermal and hematopoietic necrosis baculovirus of penaeid shrimp. Mar Fish Res (shandcag) 16:24-30

Zhan WB, Wang YH, Fryer LJ, Okubo K, Fukuda H, Yu KK, Meng QX (1999) Production of monoclonal antibodies (MAbs) against white spot syndrome virus (WSSV). J Aquat Anim Health 11:17-22

Submitted: February 2, 2002; Accepted: May 2, 2002

Proofs received from author(s): July 9, 2002 